\title{
DEVELOPMENT OF METHODS FOR IDENTIFICATION OF DESLORATADINE IN MEDICINES
}

\author{
SHEI «Ternopil state medical university named after I. Ya. Horbachevsky of MPH of Ukraine»
}

SUMMARY. Methods of identification of desloratadine in medicines by absorption spectrophotometry and TLC have been developed.

KEY WORDS: desloratadine, identification, spectrophotometery, thin layer chromatography, validation.

Introduction. The current pharmaceutical analysis has got more emphasis to satisfy our query for better understanding of physicochemical properties of pharmaceutical compounds, by the use of advanced instrumental methods. It also plays an important part for quality assurance of pharmaceutical product throughout the shelf life. The pharmaceutical industry is under increased scrutiny to constrain costs and yet consistently deliver to market safe, efficacious products that fulfill medical needs. As a part of this, drug analysis also plays an important role. Standard analytical procedure for newer drugs or formation may not be available in Pharmacopoeia; it is essential to develop new analytical methods which are accurate, precise, specific, linear, simple and rapid. Desloratadine (8-chloro-6,11-dihydro-11-(4-piperdinylidene)-5Hbenzo[5,6]cyclohepta[1,2-b]pyridine) is a medicine used to treat allergies. It is marketed under several trade names such as NeoClarityn, Claramax, Clarinex, Edem, Larinex, Aerius, Dazit, Azomyr, Deselex and Delot. It is an active metabolite of loratadine (second generation), which is also on the pharmaceutical market. Desloratadine is a tricyclic antihistamine (third generation), which has a selective and peripheral $\mathrm{H}_{1}$-antagonist action. It is an antagonist at histamine $\mathrm{H}_{1}$ receptors, and an antagonist at all subtypes of the muscarinic acetylcholine receptors. Desloratadine is a non-sedating, long-acting histamine antagonist with selective peripheral $\mathrm{H}_{1}$-receptor antagonist activity. After oral administration, desloratadine selectively blocks peripheral histamine $\mathrm{H}_{1}$-receptors, because the substance is excluded from entry to the central nervous system. It has a long-lasting effect and in moderate and low doses, does not cause drowsiness because it does not readily enter the central nervous system. Unlike other antihistamines, desloratadine is also effective in relieving nasal congestion, particularly in patients with allergic rhinitis. Analysis of desloratadine is not described in Pharmacopeia, that's why development and validation of methods for determination of desloratadine in medicines was our main aim [1]. We proposed and developed a method for spectrophotometric and chromatographic identification of desloratadine in medicines.

The aim of our study was to develop methods to identify desloratadine in medicines by methods absorption spectrophotometry and thin layer chromatography.

Materials and methods of research. The objects of the study were tablets tablets "Aerius», tablets "Deslor», tablets "Aeriallerg", Pharmacopoeial standard sample SPU desloratadine (certificate number $11 / 1-3187$ of $08 / 13 / 14$ ), purchased by the State Enterprise "Ukrainian Research Pharmacopoeial Center Quality of drugs."

Analytical equipment: UV spectrophotometer Lambda 25, Scales AVT-120-5D, measuring vessel glass and reagents that meet the SPU requirements. TLC test was carried out using Silica gel, chromatographic plates 60 F254 "Merck» (Germany) and «Sorbfil» (Russia).

In developing the technique of identification data as part of desloratadine medicines was chosen by UVspectrophotometry and TLC.

Results and discussion. We had previously studied the behavior of desloratadine in the UV spectra using in different solvents (ethanol, water R, $0.1 \mathrm{~mol} / \mathrm{l}$ solution of hydrochloric acid). The behavior of desloratadine in the UV spectrum in different solvents showed that all drugs have characteristic absorption bands in the wavelength range $(220-360 \mathrm{~nm})$. Absorption maximum of desloratadine: in ethanol when $244 \pm 2 \mathrm{~nm} ; 0.1 \mathrm{M}$ solution of hydrochloric acid at $280 \pm 2 \mathrm{~nm}$; in water - at $244 \pm 2 \mathrm{~nm}$ and $273 \pm 2 \mathrm{~nm}$ (fig.1). It makes it possible for the use of UV-spectrophotometry for analysis of desloratadine in medicines [2].

We had investigated various mobile phases (solvent system) in order to identify the optimal choice of desloratadine investigation by TLC in medicines. The factors of mobility in the studied systems of desloratadine solvents, are listed in table 1, 2 .

In order to develop methods of identification of desloratadine in different solvent system, we investigated the sensitivity of detection desloratadine. The value detection limit desloratadine and selection of optimal developers using different mobile phases are given in table 1-2. We found that desloratadine identification by TLC using a sensitive of all investigated solvents. Therefore, to identify a part desloratadine tablets can be used TLC method. Established that the most optimal Rf observed using rmobile phases: 
Оеляди літератури, оригінальні дослідження, погляд на проблему

dioxane-benzene-ammonia (25\%) (7: 12: 1) and However, the express solvent system n-butanol-acetic n-butanol-acetic acid-water (1: 1: 1). The detection acid-water (1: 1: 1) yields a solvent system dioxanelimit desloratadine in these systems is $0.2-0.4 \mathrm{mg}$. benzene-ammonia (25\%) (7: 12: 1$)$.
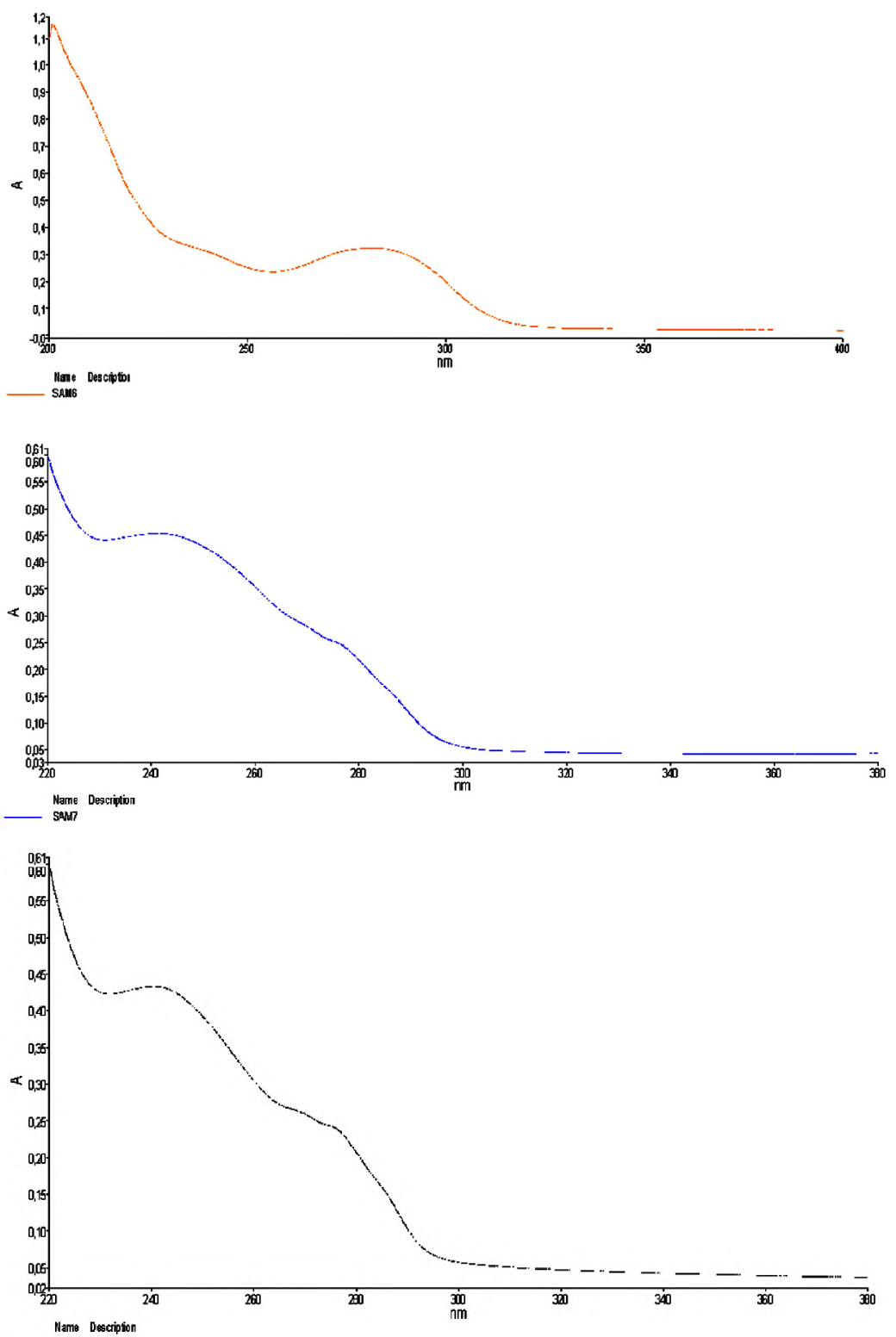

Name

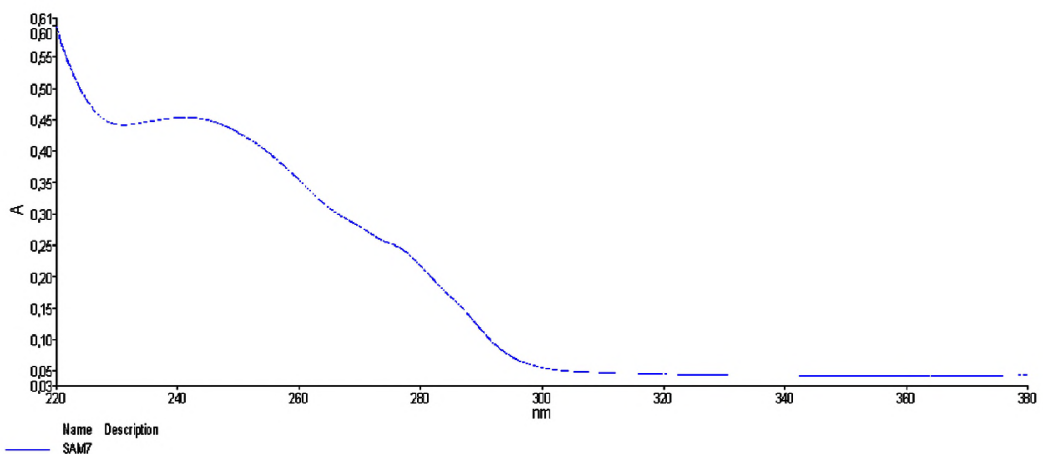

Figure 1. Electronic absorption spectra for: 1 - solution from tablets «Deslor» (in $0.1 \mathrm{~mol} / \mathrm{l}$ solution of hydrochloric acid), 2 solution from tablets «Deslor» (in ethanol), 3 - solution from tablets «Deslor» (in water R), 4 - solution Pharmacopoeial standard sample SPU of desloratadine (in ethanol). 
Оеляди літератури, ориеінальні дослідження, поеляд на проблему

Table 1. Chromatographic characteristics of desloratadine in different solvent systems

\begin{tabular}{|l|c|c|}
\hline \multicolumn{1}{|c|}{ Mobile phase } & $\begin{array}{c}\text { Stationary phase (plate) } \\
\text { Rf on «Merch» }\end{array}$ & $\begin{array}{c}\text { The limit of detection, } \\
\text { micrograms }\end{array}$ \\
\hline chloroform-acetone $(8: 2)$ & 0.05 & 0.4 \\
\hline n-butanol-methanol $(3: 2)$ & 0.18 & 0.2 \\
\hline chloroform-methanol $(9: 1)$ & 0.24 & 0.4 \\
\hline methanol-ammonia $(25 \%)(100: 1.5)$ & 0.28 & 0.4 \\
\hline dioxane-benzene-ammonia (25\%) $(7: 12: 1)$ & 0.42 & 0.4 \\
\hline toluene-acetone-ethanol,-ammonia $(25 \%)(45: 45: 7.5: 2.5)$ & 0.20 & 0.4 \\
\hline ethylacetate-methanol-ammonia $(25 \%)(85: 10: 5)$ & 0.13 & 0.6 \\
\hline n-butanol-acetic acid-water $(1: 1: 1)$ & 0.48 & 0.2 \\
\hline ethanol-acetic acid-water $(5: 3: 2)$ & 0.36 & 0.4 \\
\hline
\end{tabular}

Table 2. Chromatographic characteristics of desloratadine in different solvent systems with different developers

\begin{tabular}{|c|c|c|c|c|c|c|c|c|}
\hline \multirow[t]{2}{*}{ Substance } & \multicolumn{2}{|c|}{$\begin{array}{c}\mathrm{R}_{\mathrm{f}} \\
\text { Mobile phase }\end{array}$} & \multicolumn{6}{|c|}{ Developers (color zone) } \\
\hline & $\begin{array}{l}\text { n-butanol- } \\
\text { acetic acid- } \\
\text { water } \\
(1: 1: 1)\end{array}$ & $\begin{array}{c}\text { Dioxane- } \\
\text { benzene- } \\
\text { ammonia }(25 \%) \\
(7: 12: 1)\end{array}$ & 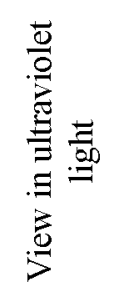 & $\sum_{1}^{+}$ & 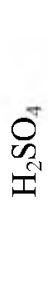 & 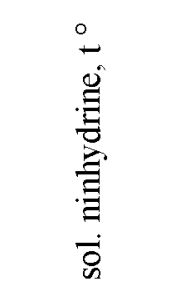 & 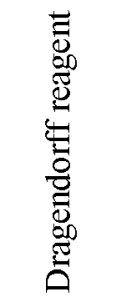 & 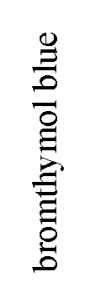 \\
\hline desloratadine & 0,48 & 0,42 & yellow & - & - & light orange & orange & $\begin{array}{l}\text { blue- } \\
\text { green }\end{array}$ \\
\hline
\end{tabular}

Thus, identification of desloratadine medicines we offer TLC-method using solvent system dioxanebenzene-ammonia (25\%) (7:12:1) and stationary phase - plate «Merch».

The analysis considered probable, though the test requirements "Check suitability chromatographic system».

Checking the suitability of the chromatographic system. Chromatographic system is considered appropriate when:

- The chromatogram obtained with reference solution is a clearly visible spot;

- Rf principal spot in the chromatogram obtained with reference solution to be about 0.6 .

Investigation solutions from tablets «Aerius», tablets "Deslor», tablets "Aeriallerg». To sample powder tablets or powder, equivalent to $0.01 \mathrm{~g}$ desloratadine, add $5.0 \mathrm{ml}$ of ethanol $R$ and dilute with ethanol $R$ to $10.0 \mathrm{ml}$, mix and filter.

Reference solution. $0.01 \mathrm{~g}$ Pharmacopoeial standard sample SPU of desloratadine dissolved in ethanol $R$ and dilute with the same solvent to $10.0 \mathrm{ml}$.

Mobile phase: dioxane-benzene-ammonia (25\%) (7: 12:1).

Samples that are applied: $50 \mathrm{mg}$, applied the test solution and investigation solutions.

Over a path of $10 \mathrm{~cm}$ from the starting line.

Developer: Dragendorff reagent.

Results: the chromatogram obtained with the test solution is detected at the main spot spots basic substance in the chromatogram obtained with reference solution, corresponding in size and color.

Below Fig. 2 shows the circuit test solutions chromatogram from tablets «Aerius», tablets «Deslor»,

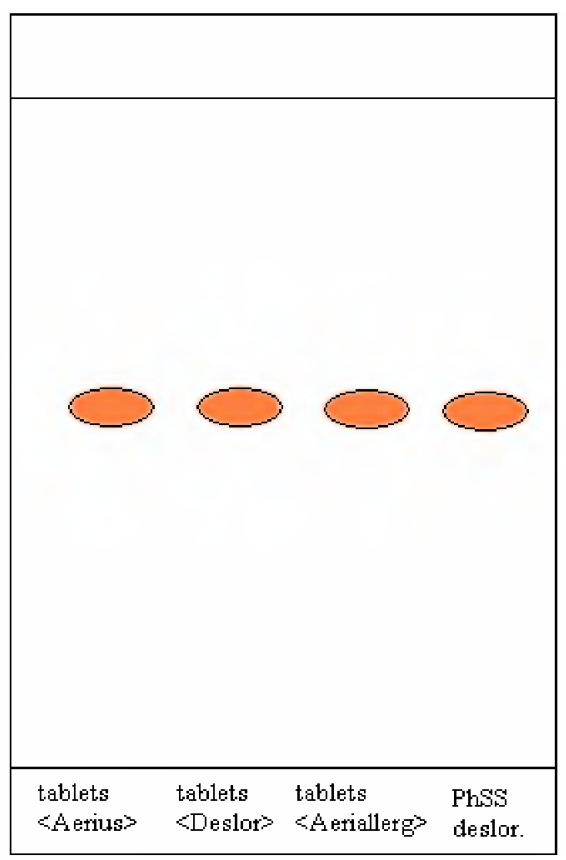

Fig. 2. Scheme of chromatogram from the solution of tablets «Aerius», tablets «Deslor», tablets «Aeriallerg» and Pharmacopoeial standard sample SPU of desloratadine in terms of identification of desloratadine desloratadine (developer-Dragendorff reagent). 
tablets "Aeriallerg» and Pharmacopoeial standard sample SPU of desloratadine in terms of identification of desloratadine.

We previously studied the behavior of placebo tablets in terms of methods of identification of desloratadine. It was established that the excipients are part of pills and do not affect the sensitivity and specificity of desloratadine detection. According to the SPU and Note for guidance on validation of analytical procedures: text and methodology (CPMP/ICH/381/95) to test the «Identification» must be validated, to determine such characteristics as specificity and suitability of the chromatographic system.

To investigate the specificity, it is necessary to confirm the selected mobility of desloratadine system to ensure proper Rf stability of solutions in time. The maximum difference of Rf values in the same plate (for two series of plates) must not exceed the value of 0.02 . Originally, plates were tested according to the requirements of SPU on chromatographic resolution.

When checking for the stability of the solution at the time we started chromatography of desloratadine freshly prepared test solution sustained, over time for $30 \mathrm{~min}$. Visual assessment of spots on the size and intensity of staining confirms that they clearly appear as freshly cooked and seasoned in time solutions (for plates of different series). The solutions were stable over time and new areas, had been identified.

Thus, we explored the validation characteristics specificity and suitability of the chromatographic system

\section{REFERENCES}

1. Liliya Logoyda. Development and validation of new methods of analysis for the determination of different natural and synthetic origin active pharmaceutical ingredients in medicines / Liliya Logoyda, Dmutro Korobko, Mohamed Mousa, Nadiya Zarivna // Duphat: Dubai International Convention \& Exhibition Centre. - Dubai, UAE. - 2015 (810 march). - P. 148.

2.Liliya Logoyda. Validation of the method for the spectrophtometric determination of desloratadine in tablets / Taty Musau Mutssi, Liliya Logoyda, Olya Polyauk// Medicine and practice XXI century, 6-7 February 2015. - Kiev, 2015. P. $135-137$.

3. Державна Фармакопея Укра ни / Державне підприємство «Науково - експертний фармакопейнийцентр». 1-е вид. - Доповнення 2. - Харків: Державне підпри that met, the eligibility criteria established by the SPU [3-5]. The objective of any analytical measurement is to obtain consistentreliable and accurate data. Validated analytical methods play a major role in achieving this goal. The results obtained from method of validation can be used to judge the quality, reliability and consistency of analytical results. It is an integral part of any good analytical practice. Validation of analytical methods is also required by most regulations and quality standards that impact laboratories. Analytical methods of validation is essential for adherence to Current Good Manufacturing Practice and Good Laboratory Practice regulations. Thus, validation studied characteristics - specificity and suitability chromatographic systems meet the eligibility criteria established by the SPU.

Conclusions. 1. To identify desloratadine in medicines and developed proposed technique UV spectrophotometry and TLC. The data on the identification of desloratadine in medicines by UV-spectrophotometry used by us in developing a method of quantitative determination of desloratadine in medicines.

2. The validation study of the characteristics of both specificity and suitability of the chromatographic system, confirmed that they meet the eligibility requirements under the SPU.

Prospects for future research will be aimed at developing methods of quantitative determination of desloratadine in medicines [6].

ємство «Науково-експертний фармакопейний центр» 2008. -620 c

4. Гризодуб А. И. Стандартные процедуры валидации методик контроля качества лекарственных средств / А. И. Гризодуб // Фармаком. - 2006. - № 1-2. - С. 35-44.

5. Руководство по валидации методик анализа лекарственных средств / Под. Ред. Н. В. Юргеля, А. Л. Младенцева, А. В. Бурдейна, М. А. Гетьмана, А. А. Малина. Москва, 2007. - 57 c.

6. Logoyda L. Development of Methodology for the Determination of Phenibut in medicines / L. Logoyda, D. Korobko, N. Zarivna // Dakam: Chemtech Chemical engineering and chemical technologies conference proceedings. - Dakam Publishing, Istanbul (Turkey). - 2014 (2325 october). - P. 141-153.

\title{
РОЗРОБКА МЕТОДИК ІДЕНТИФІКАЦІ ДЕЗЛОРАТАДИНУ В ЛІКАРСЬКИХ ЗАСОБАХ
}

\section{๑Л. С. Логойда}

\author{
ДВНЗ «Тернопільський державний медичний університет імені І. Я. Горбачевського МОЗ України»
}

РЕЗЮМЕ. Розроблено методики ідентифікаці дезлоратадину в лікарських засобах методами абсорбційно спектрофотометрі та тонкошарово хроматографі .

КЛЮЧОВІ СЛОВА: дезлоратадин, ідентифікація, спектрофотометрія, тонкошарова хроматографія, валідація. 